\title{
Investigation of tumour supressor protein p53 in renal cell carcinoma patients
}

\author{
Ingrid Hodorovaa , Peter Solarb, Jozef Mihalika, Janka Vecanovaa ${ }^{a}$, Marian Adamkovc, Silvia Rybarovaa ${ }^{a}$
}

\begin{abstract}
Background. Investigation of p53 immunoreactivity in formalin-fixed paraffin-embedded tissues of normal renal tissue and renal cell carcinoma with respect to histopathologic subtype and nuclear grade of RCC.

Methods. 42 tissue sections of RCC and 5 samples of normal renal tissue were stained for p53 expression using immunohistochemical assay. The results were analyzed in relation to nuclear grade and histopathologic subtype.

Results. In total, p53 expression was found to be 4 to 5 times higher (30.8\%) in other types of RCC than in the clearcell type of RCC (6.9\%). Further, there was no statistically significant difference in p53 overexpression among the histopathologic subtypes $(P>0.05, P=0.063)$. No association was found between the expression of p53 and nuclear grade $(P>0.05, P=0.17)$. Interestingly, our study also showed weak cytoplasmic positivity in renal tubular epithelium. Conclusion. Our findings suggest that p53 might play an important role in tumour development or progression and it might be used as a new predictor and therapeutic target for RCC.
\end{abstract}

Key words: renal cell carcinoma, expression of p53, immunohistochemistry

Received: June 23, 2011; Accepted with revision: February 28, 2012; Available online: June 1, 2012 http://dx.doi.org/10.5507/bp.2012.035

${ }^{a}$ Department of Anatomy, P. J. Safarik University, Faculty of Medicine, Kosice, Slovak Republic ${ }^{b}$ Department of Cell Biology, P. J. Safarik University, Faculty of Science, Kosice, Slovak Republic IInstitute of Histology and Embryology, Comenius University, Jessenius Faculty of Medicine, Martin, Slovak Republic Corresponding author: Ingrid Hodorova, e-mail: ingrid.hodorova@upjs.sk

\section{INTRODUCTION}

Renal cell carcinoma ( RCC) accounts for approximately $85 \%$ of all kidney cancers. There are at least five subtypes of RCC currently recognized and the most common form is clear cell cancer, which accounts for roughly $70 \%$ to $80 \%$ of cases. This tumour is characterized by exceptionally high resistance to radiation and chemotherapy $^{1}$, which can be explained in part by naturally high levels of expression of multidrug transporters and elevated activity of the glutathione system in RCC progenitors, kidney tubular epithelial cells. However, treatment resistance of tumour cells can also be associated with suppression of apoptotic mechanisms of cellular response to stress, such as the p53 tumour suppressor pathway ${ }^{2}$.

The tumour suppressor gene p53 is located on chromosome $17 \mathrm{p} 13.1$ that encodes a nuclear phosphoprotein of $53 \mathrm{kDa}\left(\right.$ ref. $\left.^{3}\right)$. It has been implicated in controlling a checkpoint during the $\mathrm{G} 1$ phase of the cell cycle, inducing cell cycle arrest and apoptosis in the presence of damaged DNA (ref. ${ }^{4}$ ). Wild-type p53 is usually not detectable by routine immunohistochemistry because of its short halflife. In contrast, the mutant p53 has a longer half-life, accumulates in the tissue, and can be easily detected in the cell nucleus. P53 appears to be mutated in about 50\% of many human cancers ${ }^{5}$, while in RCC, there is a low incidence of $\mathrm{p} 53$ mutations ${ }^{6}$. P53 mutation has been reported in $3-33 \%$ of patients with RCC ( ref. $^{7}$ ). Although p53 wild type remains wild type in the majority of RCCs, this does not mean, as we know from other tumour types, that it is functional. P53 function can be repressed by some other mechanisms, which may involve overexpression of natural negative regulators of $\mathrm{p} 53$, such as MDM2 or MDMX (ref. $^{8}$ ), or loss of positive regulators, such as Arf (ref. ${ }^{9}$ ), or by viral proteins, such as E6 of the human papilloma virus $^{10}$. There have been a number of controversial studies on the association of p53 expression and nuclear grade. While some investigators have found no association ${ }^{11}$, a strong relationship has been demonstrated by others and it is regarded as a potential marker in determining the prognosis of patients with RCC (ref. ${ }^{12}$ ).

In our study, we investigated p53 immunoreactivity in formalin-fixed paraffin-embedded tissues of normal renal tissue and renal cell carcinoma. To detect this protein, we used monoclonal antibody. Next, we conducted this study to evaluate the relationship between the overexpression of p53 tumour suppressor protein and histopathologic subtype of RCC. We also compared p53 immunoreactivity with the nuclear grade of our set of RCC as there is a dearth of published data on this connection.

\section{MATERIALS AND METHODS}

\section{Patients}

In the study, we used 42 samples of renal cell carcinoma and 5 samples of normal renal tissue. The samples were obtained from the Department of Pathology, Pasteur Faculty Hospital, Košice, Slovak Republic. 
The renal cell carcinoma samples were divided according to histopathological type into 2 groups: $1^{\text {st }}$ group - conventional type of RCC (clear cell type) = 29 samples and $2^{\text {nd }}$ group - other types of RCC ( 5 papillary, 3 chromophobe , 1 sarcomatoid , 1 multilocullar cystic and 3 unclassified types) $=13$ samples. Patients and tumour characteristics are summarized in Table 1. All samples were immunohistochemically analyzed for wild and mutant type $\mathrm{p} 53$.

\section{Antibody}

We used the following primary monoclonal antibody: mouse anti-p53, clone DO7 (BioGenex Laboratories, Inc.), which recognizes an epitope residing between amino acids 32 to 79 . This antibody is known to detect wildtype and mutated p53 in paraffin-embedded histological tissue and it is the most used antibody for detecting p53 in many diagnostic histopathological laboratories.

\section{Immunohistochemical detection of p53:}

After paraffin removal, sections were finally washed in phosphate-buffered saline containing $0.05 \%$ Tween- 20 (PBS-Tw), $\mathrm{pH}$ 7.6. Endogenous peroxidase activity was blocked by $0.3 \% \mathrm{H}_{2} \mathrm{O}_{2}$ in methanol for $30 \mathrm{~min}$ at room temperature. The slides were pre-treated in a water bath in sodium citrate buffer $0.1 \mathrm{M}(\mathrm{pH} 6.0)$ in the microwave $2 \times 5$ min for antigen retrieval. The p53 staining procedure continued by blocking nonspecific staining with milk buffer ( $5 \%$ dry milk in TRIS buffer) for $30 \mathrm{~min}$ at room temperature. The next step was primary antibody which was applied overnight in a humidified chamber at $4^{\circ} \mathrm{C}$. After rinsing in PBS-Tw $(3 \times 5 \mathrm{~min})$ the sections were subsequently incubated with the secondary antibody: prediluted biotinylated horse antibody (Vector Laboratories, USA) for $30 \mathrm{~min}$ at room temperature. The slides were rinsed with PBS-Tw and then subjected to peroxidase-conjugated streptavidine: prediluted R.T.U Vectastain (Vector Laboratories, USA) for $30 \mathrm{~min}$ at room temperature. The sections were visualized with DAB (3.3'- diaminobenzidine tetrahydrochloride) at a concentration of $0.5 \mathrm{mg} /$ $\mathrm{ml}$ in Tris buffer ( $\mathrm{pH} 7.6$ ) and $0.015 \% \mathrm{H}_{2} \mathrm{O}_{2}$. Slides were stream-rinsed with tap water, counterstained with hematoxylin for 2 min, washed in tap water, dried, mounted and coverslipped.

Sections processed with the omission of primary antibody served as negative control of immunohistochemical procedure.

\section{Immunohistochemical analysis of p53}

Immunostaining was assessed by two independent observers blinded to patient characteristics.

Expression of p53 was evaluated separately using the following scale: $3+=$ high level ( $91-100 \%$ of positive cells), $2+=$ medium level (11-90\% of positive cells), $1+=10 \mathrm{w}$ level (up to $10 \%$ of positive cells), - = negative cells $(0 \%$ of positive cells). For statistical analysis as positive were considered only samples with high level $[3+]$ and medium level $[2+]$ proteins expression. Samples scored as $[1+]$ or [-] were considered negative.
Table 1. Tumour characteristics of patients.

\begin{tabular}{|c|c|c|}
\hline & Characteristics & No. \\
\hline All patients & & 42 \\
\hline \multirow{2}{*}{ Sex } & female & 13 \\
\hline & male & 29 \\
\hline \multirow{2}{*}{ Age } & $\leq 50$ & 9 \\
\hline & $\geq 51$ & 33 \\
\hline \multirow{6}{*}{$\begin{array}{l}\text { Histo-pathol. } \\
\text { type }\end{array}$} & RCC - clear-cell type & 29 \\
\hline & RCC - papillary type & 5 \\
\hline & RCC - chromophobe type & 3 \\
\hline & RCC - multilocular cystic type & 1 \\
\hline & RCC - sarcomatoid type & 1 \\
\hline & RCC - unclassified type & 3 \\
\hline \multirow{4}{*}{$\begin{array}{l}\text { Nuclear grade } \\
\text { (Fuhrman) }\end{array}$} & 1 & 12 \\
\hline & 2 & 20 \\
\hline & 3 & 4 \\
\hline & Unknown & 6 \\
\hline \multirow{2}{*}{$\begin{array}{l}\text { p53 } \\
\text { expression }\end{array}$} & Positive & 6 \\
\hline & Negative & 36 \\
\hline \multirow{2}{*}{$\begin{array}{l}\text { Upper uri- } \\
\text { nary tract }\end{array}$} & Without malign tumour lesions & 40 \\
\hline & With malign tumour lesions & 2 \\
\hline \multirow{2}{*}{$\begin{array}{l}\text { Structures } \\
\text { of hilum }\end{array}$} & Without malign tumour lesions & 37 \\
\hline & With malign tumour lesions & 5 \\
\hline
\end{tabular}

\section{Statistical analysis}

Renal cell carcinoma samples according to subgroups (RCC-conventional type and RCC-other types) and nuclear grade were compared with respect to possible differences in p53 immunoreactivity using a two tailed Fisher's Exact Test and the Chi-square test. Other types of RCC (papillary, chromophobe, sarcomatoid, multilocullar and unclassified) were evaluated together because the number of samples in each group was too small for separate statistical analysis. $P<0.05$ was considered to be significant.

\section{RESULTS}

\section{Immunohistochemical analysis of p53}

We analysed p53 in 42 samples of RCC and 5 samples of normal renal tissue using mouse anti-p53, clone DO7 antibody. P53 immunostaining of renal cell carcinoma 

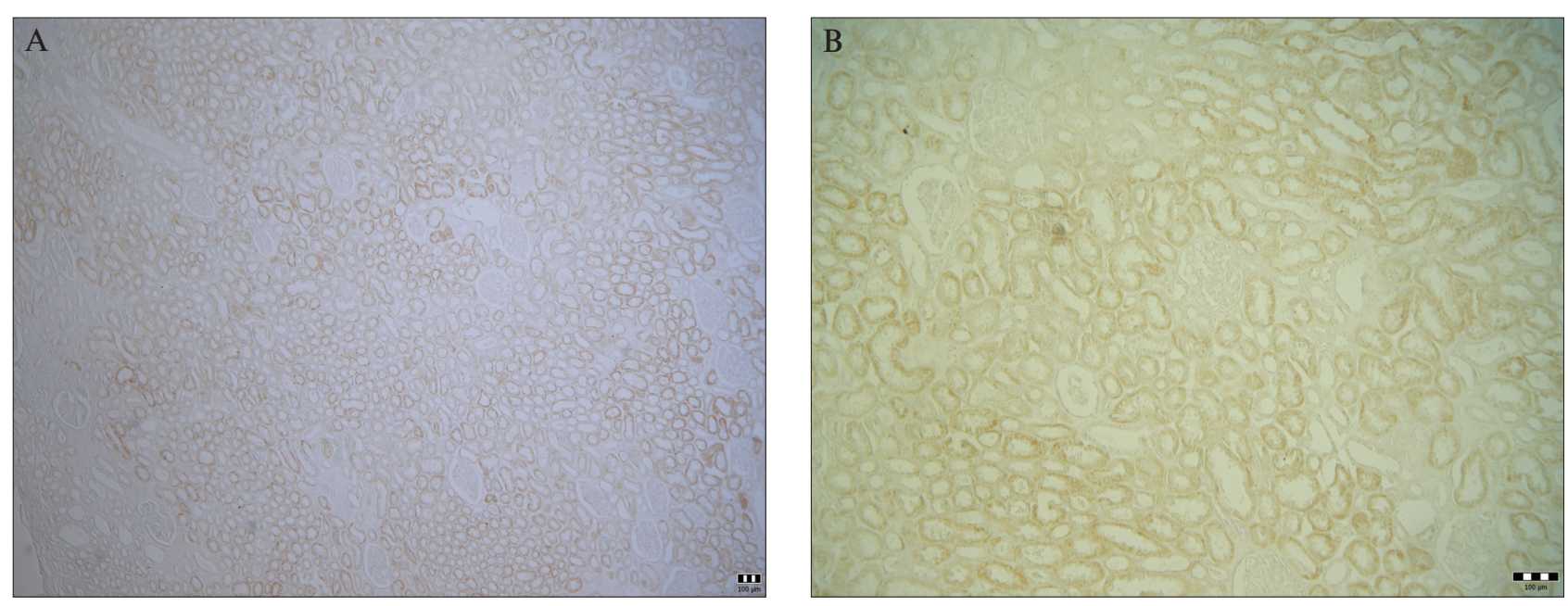

Fig. 1. Normal renal tissue - immunohistochemical detection of p53 by monoclonal antibody: mouse anti-p53, clone DO7. Positive expression of $\mathrm{p} 53$ in proximal tubular epithelial cells of normal renal kidney - cytoplasmic staining (A, B). Magnification: A - 10x10, B - 40x10.
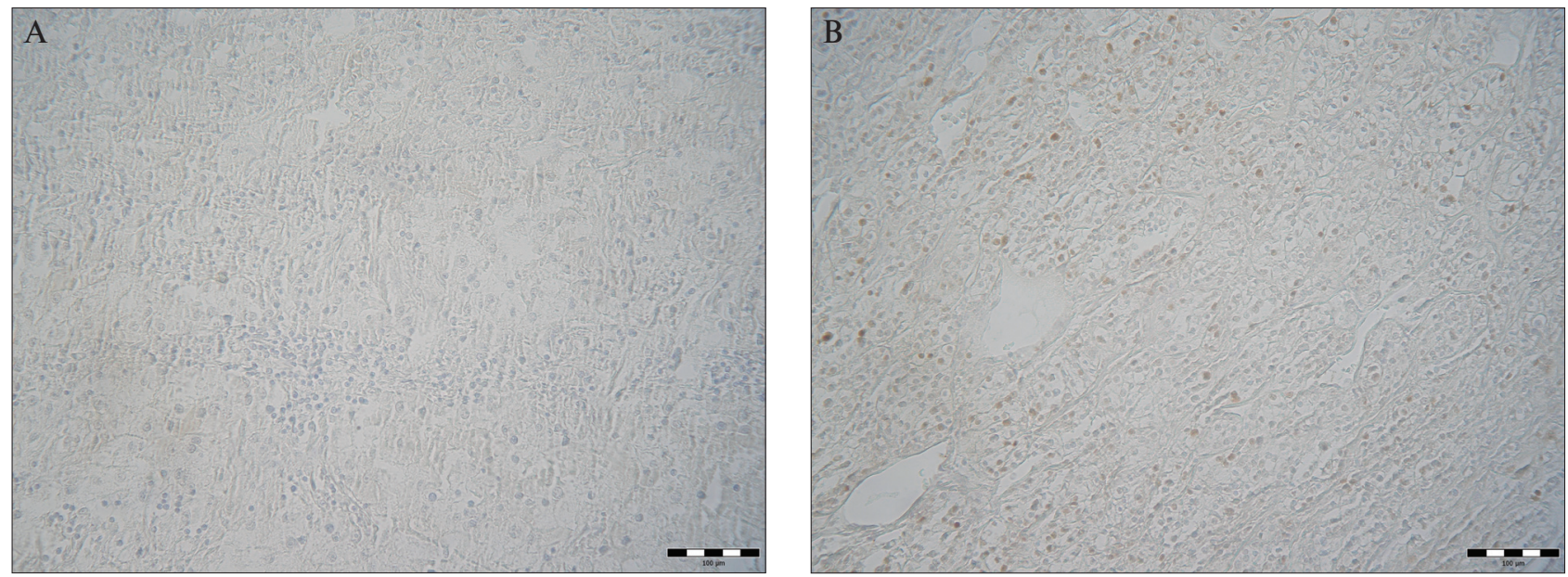

Fig. 2. RCC - conventional type: negative expression of p53. Note complete absence of $\mathrm{p} 53$ immunostaining in carcinoma cells of RCC (A). Positive expression of p53 in the nuclei of tumour cells. Immunopositive nuclei are represented by brown colour (B). Magnification: A - 40x10, B - 40x10.
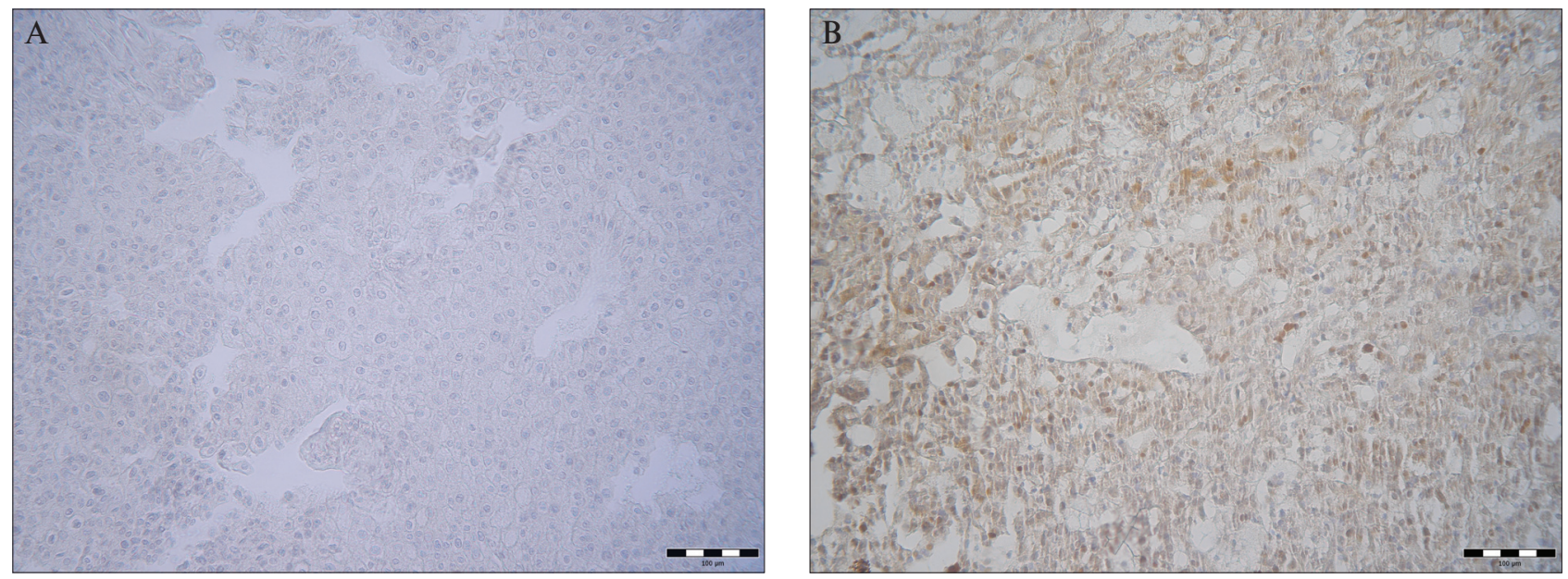

Fig. 3. RCC - other type: tumour cells show negative expression of p53 (A). Positive expression of p53 in the nuclei of tumour cell. P53 positive nuclei show brown staining (B). Magnification: A - 40x10, B - 40x10. 
tissue samples revealed nuclear localisation with nonrestriction to any particular cell type (Fig. 2b, Fig. 3b). In normal renal tissue specimens, staining of p53 showed weak cytoplasmic positivity in renal tubular epithelium (Fig. 1a,b).

In the first group (RCC: clear-cell), only one of the 29 samples expressed p53 at a very high level, in 1/29 samples medium expression level was detected, 8/29 samples showed low expression and 19/29 were p53 negative (Fig. 2a). Taken together, $6.9 \%$ of conventional and/or clear cell carcinoma cases showed p53 positivity and the rest (93.1\%) were considered negative. Some differences were obtained in p53 expression in our set of second group (RCC - other types). Strongly positive expression was detected in one of 13 cases, medium positive were $3 / 13$ samples, weakly positive expression had no cases and 9 tissue samples were p53 negative (Fig. 3a). In total, p53 expression was found to be four to five times higher in other types of RCC than in the clear-cell type of RCC.

\section{Comparison of p53 expression with histopathologic subtypes}

We found no statistically significant difference in p53 overexpression among the different histopathologic subtypes $(P>0.05, P=0.063)$. For more details concerning the expression of p53 (see Table 2).

Comparison of p53 expression with nuclear grade of RCC

Nuclear grade, a clinically relevant predictor parameter, was determined and compared with p53 expression. The comparison of this parameter was evaluated in 42 clinical samples of all histopathological types of RCC.

No statistically significant difference in p53 expression in renal cell carcinomas was found with respect to the nuclear grade $(P>0.05, P=0.17)$. The exact numbers of tissue tumour samples and the statistical analysis are shown in Table 3.

\section{DISCUSSION}

The determination of p53 status by immunohistochemistry is a widely accepted tool in surgical pathological evaluation. However, the role of p53 overexpression in RCC is still controversial ${ }^{13-15}$. The reported results regarding both the rate of immunoreactive tumours and the impact of p53 overexpression on patient's prognosis are inconsistent ${ }^{16-18}$. These divergences may be the result of low patient numbers on the one hand and different patterns of stage, nuclear grade and histopathologic subtype dependent on specimen selection on the other. Additionally, technical differences, including the use of various antibodies and staining procedures, make comparison of data difficult. Interestingly, our study also showed significant differences in p53 expression between normal and tumour tissue.

Some reports suggest that p53 is not detectable immunohistochemically in normal human tissues due to half-life of wild-type p53 $\left(\right.$ ref $^{19}{ }^{19}$ ). Despite this fact, our immunostaining for $\mathrm{p} 53$ revealed positive reaction in our set of normal human kidney. Pillai et al. ${ }^{20}$ also observed cytoplasm staining of $\mathrm{p} 53$ in epithelial cells of proximal tubules of normal human kidney. Our results confirm their findings and in addition we used the same monoclonal antibody. The accumulation of p53 in normal tissues may be related to a regulatory defect mechanism between p53 and MDM2 proteins or may result from overexpression of wild-type p53. From this it follows that, the accumulation of p53 and its immunohistochemical detection

Table 2. Various levels of p53 proteins in 42 samples of renal cell carcinoma: 29 cases of clear-cell RCC and 13 cases of other type RCC. Statistical analysis (Two tailed Fisher's Exact Test).

\begin{tabular}{ccc}
\hline Quantity of p53 expression & RCC: clear cell & RCC: other type \\
\hline$[3+]$ & $1(3.45 \%)$ & $1(7.7 \%)$ \\
{$[2+]$} & $1(3.45 \%)$ & $3(23.1 \%)$ \\
{$[1+]$} & $8(27.6 \%)$ & $0(0 \%)$ \\
{$[-]$} & $19(65.5 \%)$ & $9(69.2 \%)$ \\
Number of positive samples & $2(6.9 \%)$ & $4(30.8 \%)$ \\
Number of negative samples & $27(93.1 \%)$ & $9(69.2 \%)$ \\
Fisher's Exact Test (two tailed) & & \\
\hline
\end{tabular}

Table 3. Number/percentage of patients with positive and negative expression of p53 compared to different grading. Statistical analysis (Chi-square test).

\begin{tabular}{cccccc}
\hline p53 (number) & nuclear grade 1 & nuclear grade 2 & nuclear grade 3 & unknown & $P$ value \\
\hline p53 positive (6) & $3(50 \%)$ & $1(16.7 \%)$ & $0(0 \%)$ & $2(33.3 \%)$ & \\
p53 negative (36) & $9(25 \%)$ & $19(52.8 \%)$ & $4(11.1 \%)$ & $4(11.1 \%)$ & $P>0.05$ \\
\hline
\end{tabular}


in the cytoplasm is a marker for p53 dysfunction ${ }^{21}$. The proper interpretation of p53 cytoplasm immunopositivity remains an unresolved question.

Several relatively small studies have suggested that loss of p53 function, inferred from immunohistochemical detection in clinical samples, is relatively rare $(25 \%$, $16 \%, 2 \%$ ) (ref. ${ }^{14,22,23}$ ). Two other important articles strongly suggest that loss of p53 function is a critical event in the evolution of RCC (ref. ${ }^{17,24}$ ). In our study with a similar number of patients, the overexpression of p53 was seen in $6.9 \%$ and in $30.8 \%$ of conventional and other types of $\mathrm{RCC}$, respectively. A large, more recent study ( $\mathrm{n}=97$ ) concluded that p53 expression is present in $36 \%$ of cases ${ }^{17}$. In another even larger study of 246 RCC primary and metastatic samples, p53 overexpression was detected in $29.5 \%$ of cases ${ }^{24}$. This study also found a statistically significant difference in metastatic-free survival between p53-positive and p53-negative tumours for $\operatorname{RCC}(P=0.0005)$ and that p53 was an independent prognostic indicator $(P=0.01)$. We did not find any statistical difference in nuclear p53 overexpression among histopathologic subtypes in our set of RCC. The same result was obtained by Uhlman who investigated 175 RCCs (ref. ${ }^{16}$ ). On the other hand, the latter two studies described a statistically significant difference in p53 overexpression among histopathologic subtypes ${ }^{24,25}$. The difference in p53 overexpression might reflect alternative pathways of tumourigenesis among different subtypes, possibly related to subtype-specific genetic changes. Increased p53 protein expression was accompanied by higher grade of tumour in several studies $^{12,16}$. However, in our series of samples, no relation was found between nuclear grade and increased p53 protein expression.

Taken together, all these studies suggest that, as with other cancers, one effective way that tumours can lose p53 function is through mutation. The most common in RCC carcinogenesis is the loss of $19 \mathrm{p}$. Others are gain of 1q, loss of 16q, loss of 10q and loss of 17. Apart from the above example, with the loss of chromosome 17, which is the site where p53 is located, a reciprocal translocation between chromosomes 10 and 17 has been also document$\mathrm{ed}^{26}$. In studies of cell lines derived from renal cell carcinoma, loss of $17 \mathrm{p}$ heterozygosity has been documented at a higher frequency (48\%) than has been inferred from the above clinical studies. This presumably reflects the selection for loss of $\mathrm{p} 53$ function in cells that are better able to adapt to growth ex vivo ${ }^{27}$. It has been recently proposed that $\mathrm{p} 53$ is rarely mutated in renal cancer because it was already inactivated in a novel dominant manner that was neither MDM2 nor p14 ${ }^{\mathrm{ARF}}$ dependent ${ }^{28}$. Nevertheless, Warburton et al. ${ }^{29}$ showed that p53 function is essentially "normal" and is regulated by MDM2 to a "normal" degree and is to a lesser extent regulated by $\mathrm{p} 14^{\mathrm{ARF}}$. Binding of MDM2 to p53 can block p53 transcriptional activity by preventing it from interacting with the transcriptional machinery ${ }^{30}$. MDM2 also causes p53 degradation by targeting it for destruction by the $26 \mathrm{~S}$ proteosome. The latter effect is caused by the ability of MDM2 to act as an E3 ubiquitin ligase with specificity for p53 (among other targets) (ref. ${ }^{31}$ ). Identification of these RCC-specific p53inhibitory factors is the next step in this work. We hope that it will be helpful for the development of a new effective treatment of this notoriously difficult disease.

\section{ACKNOWLEDGEMENTS}

We gratefully thank Bc. Ivana Perunská, Mrs. Katarína Bodnárová and Mrs. Mária Zátorská for their skillful technical assistance.

This work was supported partly by VEGA grant No.1/0388/08 and partly by VEGA grant No.1/0925/11.

\section{REFERENCES}

1. Bast R, Kufe D, Pollock R, Weichselbaum R, Holland J, Frei E. Cancer medicine 2000; 5th ed. Hamilton, Ontario, Canada: B C Decker.

2. Lowe SW. Cancer therapy and p53. Curr Opin Oncol 1995;7:547-53.

3. Levine A.J, Momand J, Finlay CA. The p53 tumour suppressor gene. Nature 1991;351: 453-6.

4. Harris CC. Structure and function of the p53 tumour suppressor gene: clues for rational cancer therapeutic strategies. J Nat Cancer Inst 1996;88:1442-55.

5. Guimaraes DP, Hainaut P.TP53: a key gene in human cancer. Biochimie 2002;84:83-93.

6. Girgin C, Tarhan H, Hekimgil M, Sezer A, Gurel G. P53 mutations and other prognostic factor of renal cell carcinoma. Urol Int 2001;66:7883.

7. Michael A, Pandha HS. Renal-cell carcinoma: tumour markers, T-cell epitopes, and potential for new therapies. Lancet Oncol 2003;4:21523.

8. Oren M, Damalas A, Gottlieb T, Michael D, Taplick J, Leal JF, Maya R, Moas M, Seger R, Taya Y, Ben-Ze'Ev A. Regulation of p53: intricate loops and delicate balances. Ann N Y Acad Sci. 2002;973:374-83.

9. Sherr CJ. The INK4a/ARF network in tumour suppression. Nat Rev Mol Cell Biol 2001;2(10):731-7. Review.

10. Thomas M, Pim D, Banks L. The role of the E6-p53 interaction in the molecular pathogenesis of HPV. Oncogene 1999;18(53):7690-700. Review.

11. Bot FJ, Godschalk JC., Krishnadath KK, van der Kwast TH, Bosman FT. Prognostic factors in renal-cell carcinoma: immunohistochemical detection of p53 protein versus clinico-pathological parameters. Int J Cancer 1994;57:634-7.

12. Leonardi E, Luciani L, Reich A, Luciani LG, Dalla Palma P. Bivariate flow cytometric analysis of cytokeratin 19/dna content in renal cell carcinoma ( $\mathrm{rcc}$ ).Correlation with clinico-pathological features ( $t$ and $\mathrm{g}$ ) and $\mathrm{p} 53$ expression. A prospective study on 84 cases. Wiley Cytometry Web Site-ISAC 2000 International Congress.Available from: http://www.wiley.com/legacy/products/subject/life/cytometry/isac2000/6349.htm.

13. Vasavada SP, Novick AC, Williams BR. P53, bcl-2, and Bax expression in renal cell carcinoma. Urology 1998;51(6):1057-61.

14. Sejima T and Miyagawa I. Expression of $\mathrm{BCl}-2, \mathrm{p} 53$ oncoprotein and Bax expression in renal cell carcinoma. Eur Urology 1999;35:242-8.

15. Uchida T, Gao JP, Wang C, Jiang SX, Muramoto M, Satoh T, Minei S, Shimura S, Irie A, Kameya T, Baba S.Clinical significance of $\mathrm{p} 53, \mathrm{mdm} 2$, and bcl-2 proteins in renal cell carcinoma. Urology 2002;59(4):615-20.

16. Uhlman DL, Nguyen PL, Manivel JC, Aeppli D, Resnick JM, Fraley EE, Zhang G, Niehans GA. Association of immunohistochemical staining for p53 with metastatic progression and poor survival in patients with renal cell carcinoma. J Natl Cancer Inst 1994;5;86(19):1470-5.

17. Haitel A, Wiener HG, Baethge U, Marberger M, Susani M. Mdm2 expression as a prognostic indicator in clear cell renal cell carcinoma: comparison with p53 overexpression and clinicopathological parameters. Clin Cancer Res 2000;6(5):1840-4.

18. Rioux-Leclercq N, Turlin B, Bansard J, Patard J, Manunta A, Moulinoux JP, Guillé F, Ramée MP, Lobel B. Value of immunohistochemical Ki-67 
and $\mathrm{p} 53$ determinations as predictive factors of outcome in renal cell carcinoma. Urology 2000;55(4):501-5.

19. Dippold WG, Jay G, DeLeo AB, Khoury G, Old LJ. P53 protein transformation-related protein: detection by monoclonal antibody in mouse and human cells. Proc Natl Sci USA 1981;78:1695-9.

20. Pillai G, Roberts H, Gatter K, Pezzela F.P53 expression in normal paraffin-embedded tissue using different antibodies and antigen retrieval buffer systems. Histopathology 2003;42:83-7.

21. Huang J, Soffer SZ, Kim ES, Yokoi A, Moore JT, McCrudden KW, Manley C, Middlesworth W, O'Toole K, Stolar C, Yamashiro DJ, Kandel JJ.P53 accumulation in favorable-histology Wilms tumour is associated with angiogenesis and clinically aggressive disease. Journal of Pediatric Surgery 2002;3:523-7.

22. Tomasino RM, Morello V, Tralongo V, Nagar C, Nuara R, Daniele E, Curti M, Orestano F. P53 expression in human renal cell carcinoma: an immunohistochemical study and a literature outline of the cytogenetic characterization. Pathologica 1994;86:227-33. Review.

23. Hofmockel G, Wittmann A, Dammrich J, Bassukas ID. Expression of p53 and bcl-2 in primary locally confined renal cell carcinomas: no evidence for prognostic significance. Anticancer Res 1996;16:380711.

24. Zigeuner R, Ratschek M, Rehak P, Schips L, Langner C. Value of p53 as a prognostic marker in histologic subtypes of renal cell carcino- ma: a systematic analysis of primary and metastatic tumour tissue. Urology 2004;63:651-5.

25. Ljungberg B, Bozoky B, Kovacs G, Stattin P, Farrelly E, Nylander K, Landberg G. P53 expression in correlation to clinical outcome in patients with renal cell carcinoma. Scand J Urol Nephrol 2001;35:1520.

26. Punnet $\mathrm{HH}$, Halligan GE, Zaeri N, Karmazin N. Translocation 10;17 in clear cell sarcoma of the kidney. A first report. Cancer Genet Cytogenet 1989;74:264-8.

27 Reiter RE, Anglard P, Liu S., Gnarra JR, Linehan WM. Chromosome $17 p$ deletions and p53 mutations in renal cell carcinoma. Cancer Res 1993;53:3092-97.

28. Warburton HE, Brady M, Vlatkovič N, Linehan WM, Parsons K, Boyd MT. P53 regulation and function in renal cell carcinoma. Cancer Res 2005;65:6498-503.

29. Gurova KV, Hill JE, Razorenova OV, Chumakov PM, Gudkov AV. P53 pathway in renal cell carcinoma is repressed by a dominant mechanism. Cancer Res 2004;64:951-58.

30. Thut CJ, Goodrich JA, Tjian R Repression of p53-mediated transcription by MDM2: a dual mechanism.. Genes Dev 1997;11(15):1974-86.

31. Kubbutat $\mathrm{MH}$, Jones SN, Vousden KH Regulation of p53 stability by Mdm2.. Nature. 1997;387(6630):299-303. 